DOI https://doi.org/10.36059/978-966-397-152-0/1-21

\title{
THE SIGNIFICANCE OF PROBLEM-SOLVING IN THE PROFESSIONAL ACTIVITY
}

\section{Maryna Smulson}

\section{INTRODUCTION}

The aim of the article is to show the place of a problem in the structure of professional activity as well as psychological problems of training personnel for setting and solving professionally-oriented problems. We onward rely on the elaborations of the Ukrainian scientists, which were called "problem-based approach to the activity". Corresponding researches were initiated at H. S. Kostiuk Institute of Psychology at the National Academy of Pedagogical Sciences of Ukraine in the early 1970-s under the direct leadership of H. Kostiuk and V. Glushkov. In this direction, many interesting theoretical and applied projects have been carried out, in particular, by G. Ballom, T. Gergey, O. Dovgiallo, Yu. Mashbits, M. Smulson, O. Stognii, E. Yushchenko and other Ukrainian psychologists and cyberneticists. According to the problem-based approach, any activity of the subject, in particular professional one, can be described as a system of processes for solving problems of different sorts and types. A problem is a unit of activity that displays all of its features, from the motive to the problem-solving tools and relative operations. Therefore, according to S. Maksimenko, a problem is a "universal technique of organizing human activity".

In the professional activity, we first of all distinguish problems concerning career, which clearly correspond to the meaning and purpose of the professional activity (for example, didactic problems for the teacher, research - for the scientist, legal - for the lawyer, etc.).

1 Maksymenko, S. D. (2019). Aktualni problemy henetychnoi psykholohii [Actual Problems of Genetic Psychology] Aktualni problemy psykholohii: Zb. nauk. prats Instytutu psykholohii imeni H. S. Kostiuka NAPN Ukrainy. [Actual problems of psychology: Collection of scientific works of the H.S. Kostiuk Institute of Psychology of the National Academy of Pedagogical Sciences of Ukraine.] T. U111, Psykholohichna teoriia $\mathrm{i}$ tekhnolohiia navchannia [Psychological Theory and Technology of Learning], vol. 10., Kyiv., S. 15 [in Ukrainian]. 
At the same time, accomplishing a professional activity is impossible without solving problems that fall within organizing activity, including joint tasks as well as personal interaction and interaction of professional groups, and, surely, the tasks of professional selfimprovement, that is, professional self-design and self-development. Definitely, there are many more types of problems in professional activity. However, essentially all problems, as shown below, grow out of problem situations and require intellectually creative efforts, in other words, make professional activities intellectually rich.

\section{General Characteristics of the Problem-Based Approach to the Activity. Task and Intellect}

The well-known definition of the problem proposed by G. Ball is based on the concept of 'system, 2,3 " A problem, in its most general form, is a system whose obligatory components are a) an object of the problem, which is in the initial state (hereinafter, the original object of the problem); b) a model of the desired state of the object of the problem (we identify this model with the requirement of the problem)" ". To define a problem, which is considered as such a system, G. Ball uses the term 'problem system'. Evidently, the problem is interpreted by G. Ballom quite broadly, and such an interpretation is necessary to construct the concept of a problem approach to the activity.

Justifying this concept, G. Ball writes: "If the concept of a problem is interpreted quite broadly, then the activity of the subject can be represented as a system of processes for solving problems. We emphasize that this applies not only to the regulatory but also to the

2 Ball, G. A. (1990) Teoriia uchebnykh zadach: Psikhologo-pedagogicheskii aspekt [Theory of Educational Problems: Psychological and Pedagogical Aspect]. M.: Pedagogika. $184 \mathrm{~s}$.

${ }^{3}$ Ball, G. A. (2019). Bazovyie poniatiia obshchei teorii zadach. [Basic Concepts of the General Theory of Problems.] ... // Aktualni problemy psykholohii: Zb. nauk. prats Instytutu psykholohii imeni H. S. Kostiuka NAPN. Vol. U111, Psykholohichna teoriia i tekhnolohiia navchannia [Psychological Theory and Technology of Learning], vol. 10. Kyiv, 33-55. [in Russian]

4 Ball, G. A. (1990) Teoriia uchebnykh zadach: Psikhologo-pedagogicheskii aspekt [Theory of Educational Problems: Psychological and Pedagogical Aspect]. M. : Pedagogika. S. 31. 
creative components of the activity: the problems, actually solved by the subject, express not only the external demands placed on him, but also the strand of his personality. Highlighting the problems that are being solved by the subject, as well as the means and ways of solving them, establishing the qualitative and quantitative characteristics of these tasks help research and design activities. In particular, the possibilities of distinguishing their age, individual and other peculiarities, comparison of problems, actually solved by the subject with the problems that are set before them or are to be solved by them in this situation are extending"5.

G. Ball distinguishes a problem-system from a problem situation (a set of objects that admits a system representation as a problem but has not yet received such a representation) and a sign model of the problem, in particular, its verbal description (formulation of the problem).

In its turn, the system that provides the solution to the problem, in an extended sense, is called the solver by G. Ball. He borrowed the term from cybernetics. Therefore, he notes that animals, humans, groups of people, technical devices and others can act as solvers. Essentially, he proposes to characterize the solver by the set of problem-solving means, he / she has at his disposal. The problems are proposed to be considered both taking into account the characteristics of the solver as well as abstracting from them ${ }^{6}$.

It is implicitly considered that the solver and the problem raiser are different systems (people, groups, technical devices, etc.). It is clear that this situation certainly takes place when learning problems are solved, when the problems for a student are selected or created by the teacher precisely to train the use of appropriate problem-solving tools. However, this is only one of the possible options. The article

5 Ball, G. A. (1990) Teoriia uchebnykh zadach: Psikhologo-pedagogicheskii aspekt [Theory of Educational Problems: Psychological and Pedagogical Aspect]. M.: Pedagogika. P. 5-6.

6 Ball, G. A. (1990) Teoriia uchebnykh zadach: Psikhologo-pedagogicheskii aspekt [Theory of Educational Problems: Psychological and Pedagogical Aspect]. M.: Pedagogika. $184 \mathrm{~s}$.

7 Ball, G. A., Margulis, Ye. D., Rybalka, V. V., Chmut. T. K., Samoylov, A. Ye. (1983). Issledovaniia protsessa postanovki zadachi i ikh pedagogicheskoye znacheniye [Investigations of the Problem Setting Process and Their Pedagogical Significance]. // Programmirovannoye obucheniye [Programmed Training]. Vyp. 20. Kiyev. 
analyzes relevant experimental studies conducted by colleagues under the guidance of G. Ball, investigates the process of setting mental and organizational problems within the framework of fulfilling practical tasks that are set outside. These are service situations for checking the availability of a tool given to two employees of different shifts (T. Chmut's research); tasks for operating computers (O. Samoilov's research); design problems (V. Rybalka's research) and tasks for setting problems in group work (E. Margulis's research). In the last study, in particular, the focus was on setting group-specific tasks and its organization. It was found out that such problems were not spotted or actualized by pairs, but sometimes were spotted in the group of three people, however were often ineffectively solved, that is, the resolution activities were carried out by one or two tested persons, and the third was passively awaiting the results.

Although, relevant researches were conducted more than thirty years ago and bears convincing evidence about the importance of setting problems without any assistance for the evolvement of cognitive activity and creative initiative, it can have been stated so far that "relevant skills are purposefully formed neither in secondary school, nor in the vocational education system, nor in higher education establishment" ${ }^{\text {" }}$.

However, in the traditions of H. Kostiuk's scientific school, it is necessary to build psychological and pedagogical approaches taking into account their developmental potential and possibilities of further enrichment and modernization $9,10,11$. G. Ball rightly

${ }^{8}$ Ball, G. A., Margulis, Ye. D., Rybalka, V. V., Chmut. T. K., Samoylov, A. Ye. (1983). Issledovaniia protsessa postanovki zadachi i ikh pedagogicheskoye znacheniye [Investigations of the Problem Setting Process and Their Pedagogical Significance]. // Programmirovannoye obucheniye [Programmed Training]. Vyp. 20. Kiyev. [in Russian]

${ }^{9}$ Kostiuk, H. S. (1969). Princip razvitiia v psihologii [The Development Principle in the Psychology]. Metodologicheskiie i teoreticheskiie problemy psihologii [Methodological and Theoretical Problems of Psychology]. M. : Nauka [in Russian].

10 Maksymenko, S. D. (2019). Aktualni problemy henetychnoi psykholohii [Actual Problems of Genetic Psychology] Aktualni problemy psykholohii: Zb. nauk. prats Instytutu psykholohii imeni H. S. Kostiuka NAPN Ukrainy. [Actual problems of psychology: Collection of scientific works of the H. S. Kostiuk Institute of Psychology of the National Academy of Pedagogical Sciences of Ukraine.] T. U111, Psykholohichna teoriia $\mathrm{i}$ tekhnolohiia navchannia [Psychological Theory and Technology of Learning], vol. 10., Kyiv. 8-20 [in Ukrainian]. 
points out that problems (sign models of problems), which have the same normative meaning, do not always have the same meaning for the solver" ${ }^{12}$ In this respect, we recollect the concept of "additional definition" of a problem, introduced by Y. Mashbits ${ }^{13}$, according to which, under the influence of various intellectual and motivational factors, a student transforms a specified external problem into a problem in a psychological sense, that is, not only spots an object but also comes to grips with his / her own learning activities. "A problem additional definition can be pictured as a projection of actualized goal-drives for a subject at a specified moment (they reflect both the personal meaning of the students and certain situational factors), as well as the intellectual properties (abilities, knowledge and skills, subjective world as a whole) to an externally set task" ". An additional definition and even a new definition of the problem contribute to the development of the person, who solves the problem (the solver), that is, it can facilitate the achievement of learning goals, especially distant ones, such as the development of cogitation, imagination, reflection as well as students' own activity mastery.

However, in our opinion, the most effective in terms of selfeducation and accordingly intellectual self-development is the situation

11 Chepelieva, N. V. (2019). Rozviazannia smyslovykh zadach yak chynnyk samoproektuvannia osobystosti [Solving Meaningful Problems as a Factor of SelfDesign of Personality]. Aktualni problemy psykholohii: Zb. nauk. prats Instytutu psykholohii imeni H. S. Kostiuka NAPN Ukrainy [Current Problems of Psychology: a collection of scientific works of H. S. Kostiuk Institute of Psychology of the National Academy of Pedagogical Sciences of Ukraine]. T. U111, Psykholohichna teoriia i tekhnolohiia navchannia [Psychological Theory and Technology of Learning], vol. 10. K., P. 300-313 [in Ukrainian].

${ }^{12}$ Ball, G. A. (2019). Bazovyie poniatiia obshchei teorii zadach. [Basic Concepts of the General Theory of Problems]. ... // Aktualni problemy psykholohii: Zb. nauk. prats Instytutu psykholohii imeni H. S. Kostiuka NAPN. Vol. U111, Psykholohichna teoriia i tekhnolohiia navchannia [Psychological Theory and Technology of Learning], vol. 10. Kyiv, 33-55. [in Russian]

13 Mashbyts, Yu. I. (2019). Psykholohichni mekhanizmy i tekhnolohiia navchannia [Psychological mechanisms and technology of teaching]. K.: Interservis [in Ukrainian].

14 Mashbyts, Yu. I. (2019). Psykholohichni mekhanizmy i tekhnolohiia navchannia [Psychological mechanisms and technology of teaching]. K.: Interservis [in Ukrainian]. S. 33. 
of self-assignment when the problem-maker and problem-solver is one and the same person, that is, they merge into one person, who finds for himself / herself a specified (problem) situation. This person constructs its sign model (transforms into a problem) and then solves the problem according to their own systems of tools, sometimes creatively developing and supplementing them.

Based on the problem-based approach, we believe that intellectual activity is initiated (triggered) in a problem situation, which transforms into a task when it is independently set. Any situation, whether practical or theoretical, can be defined as a problem one, which has no obvious decision fitting the circumstances and that is why it requires ground state and cogitation. Depending on how the situation is perceived by the subject, the problem setting either takes place or does not.

A problem setting stage needs consideration in all tasks, but especially in those that arise in practical work. Detection of a future problem - a problem situation - is one of the most important properties of an expert's intellect. The problem situation is often not fully recognized and exists to the extent that the person, who invented it, has something to with it.

The problem differs from the problem situation as it is recognized by the subject, objectified and most often described verbally or in a different sign (numeric, graphic) form. The problem statement contains its analysis and understanding at a certain level, preliminary definition of the decision conception, strategy, action plan. It usually involves consideration of possible realistically available problem solving tools (ie material, materialized and ideal objects that do not directly enter the conditions of the problem but are involved in solving it) ${ }^{15}$.

Therefore, a problem, that is, its independent statement, is an ontological substrate for such metacognition, which we call intellectual initiation ${ }^{16}$. We are not inclined to agree with M. Kholodnaia's critics of problems as the ones that deontologizes

15 Smulson, M. L. (2003). Psykholohiia rozvytku intelektu: monohrafiia [Psychology of Development of Intellect: Monograph], K. : Nora-Druk[in Ukrainian].

${ }^{16}$ Smulson, M. L. (2009). Intelekt i mentalni modeli svitu [Intellect and Mental Models of the World] / Naukovi doslidzhennia kohnityvnoi psykholohii [Scientific and Cognitive Psychology]. Ostroh: Vyd-vo Natsionalnoho universytetu "Ostroh", Vol. 12, 38-49 [in Ukrainian]. 
intellect $^{17}$. She believes that the problem-based approach specific for intelligence scale is diagnosed not by the type of intellectual organization but by the problem-dependent response style. In other words, fair criticism here is limited to a wrong emphasis on the result rather than the process and the apparent artificiality of the test tasks, but one cannot agree that the problem is the one, which deontologizes the intellect. In our opinion, the task itself neither detect, nor diagnose intellect, nor deontologizes it in any way, it launches it, that is, initiates intellectual activity. Moreover, we use the term "problem" as a basic semantic construct in defining intellect and analyzing the process of its development. From our point of view the intellect is a holistic (integral) mental formation that is responsible for the creation, construction and restructuring of mental models of the world by setting and solving problems (for more information about the significance of the problem in intellectual activity ${ }^{18}$ ).

In the context of professional activity, we consider the mental model of the world as the result of intellectual processing (reflection, awareness, fixation and interpretation) by a professional of personal experience, recorded in a reduced form (for example, in the form of self-narrative). Mental models capture the content and level of understanding of a person's self, others and the environment, closely related to knowledge and beliefs, so they can be considered as a stable intellectual characteristic of a professional. A serious transformation of the mental model system is usually interpreted as a sign of selfmovement and self-development.

On the other hand, the mental model can be regarded as a kind of interpretation filter. The basic directions of constructing a mental model are the sense or, otherwise, the value-oriented basis (life, one's own professional activity, etc.), the chronotope, or temporal-spatial

17 Kholodnaia, M. A. Psikhologiya intellekta [Psychology of Intelligence]. Paradoksy issledovaniia [Paradoxes of Research]. Moskva-Tomsk: Izd-vo Tom. un-ta, 1997. $392 \mathrm{~s}$.

${ }^{18}$ Smulson, M. L. (2017). Mistse zadachi v intelektualnii diialnosti // Pedahohika i psykholohiya: Visnyk NAPN Ukrayiny [The Place of the Problem in Intellectual Activity // Pedagogy and Psychology: Bulletin of the National Academy of Pedagogical Sciences of Ukraine]. № 2 (95). S. 40-48. 
coordinates, as well as an aspect of a significant other (others, reference group) as an interactive (decentralized) substructure of the mental models ${ }^{19}$.

The structure of intellect is formed by the basic mental processes, that is, the system of cognitions, as well as metacognitions: intellectual initiation (self-assignment), decentralization, reflection and strategic fit ${ }^{20}$.

They are their own, independently set problems that initiate the development and self-development of intellect. Used as a problem, all structural components of intellect, both cognitive and metacognitive ones, interact and integrate, enter into a coalition at every timepoint, providing appropriate amplification and transformation of mental models of the world.

The dynamics of metacognitions determine the potential for the development and self-development of intellect as a whole. At the same time, as we stated above, intellectual initiation corresponds to the independent formulation of the problem, and the intellect develops best if the problem is independently spotted and assigned. To launch the intellectual processes, it is necessary to have a problem that the subject feels, sees, etc., turns it into a task and begins to work on it, to solve it.

A. Karpov ${ }^{21}$, explaining the special role of metacognitive processes in the structure of consciousness, notes that they are all aimed at organizing, regulating, and coordinating others - the "primary" cognitive processes. Therefore, metacognitive processes are such procedural means that, by mastering them, the subject largely becomes the one, that is, he / she acquires "self" and subjectness not

19 Smulson, M. L. (2019). Rozvytok dorosloi liudyny u suchasnomu tranzytyvnomu sviti [Adult development in the modern transitive world]. Aktualni problemy psykholohii: Zb. nauk. prats Instytutu psykholohii imeni H.S.Kostiuka NAPN Ukrainy [Current problems of psychology: a collection of scientific works of the H.S. Kostiuk Institute of Psychology of the National Academy of Pedagogical Sciences of Ukraine]. T. U111, Psykholohichna teoriia i tekhnolohiia navchannia [Psychological theory and technology of teaching], vol. 10, Kyiv, 257-267 [in Ukrainian].

20 Smulson, M. L. \& oth. (2015). Intelektualnyi rozvytok doroslykh u virtualnomu osvitnomu prostori: monohrafiia [Adult intellectual development in the virtual educational space: a monograph]. Kyiv : Pedahohichna dumka. URL: http://lib.iitta.gov.ua/10064. [in Ukrainian].

21 Karpov, A. V. (2011). Psikhologiia soznaniia: Metasistemnyi podkhod [Psychology of Consciousness: Metasystem Approach]. M.: RAO. 1088 s. 
only in relation to the external world, but also in relation to the inner world - one's own psyche, its contents.

In this concept, intellect is the only one, there is no schematic, social, emotional, professional or any other intellect. This understanding is in line with the B. Teplov's principle of unique intellect $^{22}$. The problems that intellect fulfills at each particular time are different. The development of intellect is that it is enriched, amplified, that is, metacognitions begin to actively work with the new problems, for example, not only with the professional, but also with those a person faces in the society, or vice versa.

\section{Psychological Principles of Pre-Starting Procedure for Solving Professional Problems}

Both cognitions and metacognitions have fundamental differences when it comes to the professional, true-to-life problems, on the one hand and learning ones, on the other hand. In view of this, Y. Kornilov notes that when comparing specific features of professional and trueto-life problems (multifacetedness, continuity, dynamics, immensity, efficiency, irreversibility) with the features of common learning problems it becomes clear that the latter are characterized by contradictions. (one-sidedness, discontinuity, static character, readability, inactivity, reversalness $)^{23,24}$.

Learning problem, even if taken from the professional sphere or from real life, is discharged of the special bonds which it has been associated with, respectively, with the career process or with life. It is, as already stated, was given to the student externally, and therefore he

22 Teplov, B. M. (1961). Um polkovodtsa [The Mind of the Commander]. I B.M.Teplov // Problemy individual'nykh razlichiy [Problems of Individual Differences]. M.: APN RSFSR. S. 252-344.

23 Kornilov, Yu. K. (1997). O razlichiiakh metakognitsii uchebnoy i professionalnoi deiatelnosti [About the Differences in Metacognitions of Educational and Professional Activities]. // Kognitivnoie obucheniie: sovremennoie sostoianiie i perspektivy [Cognitive Learning: Current Status and Prospects]. / Pod red. T. Galkinoy i E. Lourera. M.: Izd-vo «Institut psikhologii RAN». S. 191-200.

${ }^{24}$ Kornilov, Yu. K. (2014). Na puti k psikhologii prakticheskogo myshleniia [On the Way to the Psychology of Practical Thinking]. M.: Izd-vo «Institut psikhologii RAN». $407 \mathrm{~s}$. 
is not required to find the problem on his / her own. Therefore, the learning problem does not teach the student the most important skill of the problem-based approach to activity - the "art" of seeing the problem. On the other hand, standard learning activity prepares itself for error-free activity, extremely strictly treating any student error in solving the problem.

According to $\mathrm{Yu}$. Mashbits ${ }^{25}$ learning problems are fundamentally different from production, professional ones. They occupy a specific place in the activity. In any work activity, both production as well as theoretical and cognitive ones, the solution of the problem is the purpose of the activity and acts as its direct product. However, in learning activity, the result of problem solving does not make sense in itself, apart from the problem solving process as an indicator of its progress. So, in the learning activity, problem solving is not its goal, but a means of achieving a goal.

However, how can you teach a professional without going through a training phase, solving a job's professional problems?

There is a serious and difficult to solve problem: how to eliminate this rigid opposion of the learning and the real problems, the approximation of the relevant metacognitions. The fundamental point in this aspect is the orientation of the psychological and pedagogical content of the learning problems (ie, the methods of action and strategies) at the corresponding content of the real ones.

It is worth reminding that the basic characteristic of intellectual initiation we consider subjectness and independence, that is, the impulse to tackle the difficult true-to-life or professional problem, looking for resources to solve it and analyzing not only the result, but also the process of achieving this result. At the same time, the fundamental and very interesting moment of the modern decisionmaking concept in complex and complicated situations is the refusal to focus on error-free activities.

25 Mashbyts, Yu. I. (2019). Psykholohichni mekhanizmy i tekhnolohiia navchannia [Psychological mechanisms and technology of teaching]. K.: Interservis [in Ukrainian]. 
G. Klein ${ }^{26}$ refers to D. Kahneman's research on decision-making in an uncertain situation ${ }^{27,28}$, noting that they have become of particular importance now, in the new century, because it is clear that people do whatever it takes to solve problems and make decisions in the real life. They do not generate alternatives, they do not estimate their probabilities, they do not weigh the advantages and disadvantages to compare these alternatives, they do not build decision trees although such strategies are considered to be the most rational. In other words, the classic normative approach to decision-making does not provide an understanding of how expert professionals act in making urgent decisions in complex situations, which are certainly linked to crisis true-to-life and professional conditions.

That is why a new paradigm has emerged that considers decision-making in unique situations of extreme professional activity, known as "naturalistic decision making"29, 30. The main characteristic of the approach is, first of all, the rejection of generalized abstract decision-making models, since expert's decisions depend on the unique features of the particular situation. The options available to the subject are unknown and are being opened during the problem solving process.

The person in the problem solving process does not compare the options, if he / she immediately finds an alternate that leads to a satisfactory solution, then in times of scarcity, he / she uses it (because the situation may change irreversibly during reflection).

${ }^{26}$ Klein, G. (2008). Naturalistic Decision Making. Human Factors / Klein G. // The Journal of the Human Factors and Ergonomics Society. 50(3). P. 456-460.

27 Kaneman, D. (2014). Dumai medlenno... reshai bystro [Think Slowly ... Decide Fast]. / Daniel Kaneman M.: AST. - 315 s. [in Russian].

28 Kaneman, D., Slovik, P., Tverski, D. (2018). Prinyatiie reshenii v neopredelennosti. Pravila i predubezhdeniya [Decision Making in Uncertain Situations: Rules and Biases]. KH. : Izd-vo «Gumanitarnyi Tsentr». $536 \mathrm{~s}$. [in Russian].

${ }^{29}$ Klein, G. (2008). Naturalistic Decision Making. Human Factors / Klein G. // The Journal of the Human Factors and Ergonomics Society. 50(3). P. 456-460.

${ }^{30}$ Knauff, M., Wolf, A. G. (2010). Complex Cognition: the Science of Human Reasoning, Problem-Solving, And Decision-Making / Knauff M., Wolf A. G. // Cognitive Processesing. 11 (2) P. 99-102. 
And again: there is no point in finding deviations from normative models and interpreting them as erroneous. O. Poddiakov ${ }^{31}$, analyzing this approach, notes that "in situations of high complexity, the very concept of error becomes ambiguous; it loses the meaningfulness and clarity of the criteria for distinguishing between errors and no mistakes... In general, under unstable conditions, rigid attitudes towards error-free activity are not adaptive".

On the other hand, activities under the circumstances of the guideline removal of infallibility also imply a high level of subjectness, that is, the willingness to be responsible for both self-selected, assigned and solved problems, as well as for the irreversible results of the choices and decisions made.

Thus, we have demonstrated that in a specifically organized learning activity under the conditions of intellectual training ${ }^{32}$, this disagreement is removed to some extent.

Our learning problems designed for training acquire the main features of true-to-life problems - namely, multifacetedness, continuity, dynamics, immensity, efficiency. However, it is obvious that in a safe artificial training environment, learning problems could not acquire implementation-related features, that is their irreversibility, which promotes high responsibility for intellectual activity.

We describe the features of intellectual training as an environment for learning to set and solve professional tasks ${ }^{33}$. One of the fundamental properties of an intellectual training environment is its intellectual saturation, which is achieved by creating problem situations of different content and structure and building appropriate psychotechnical procedures on their basis.

31 Poddiakov, A. N. (2015). Psikhologiia obucheniia v usloviiakh novizny, slozhnosti, neopredelennosti [Yelektronniy resurs] [The psychology of Learning in the Context of Novelty, Complexity, Uncertainty [Electronic resource]. / A. N. Podd'yakov // Psikhologicheskiye issledovaniya [Psychological research]. T. 8, № 40. S. 6. URL: http://psystudy.ru

32 Smulson, M. L. (2003). Psykholohiia rozvytku intelektu: monohrafiia [Psychology of Development of Intellect: Monograph], K. : Nora-Druk [in Ukrainian].

33 Smulson, M. L. (2003). Psykholohiia rozvytku intelektu: monohrafiia [Psychology of Development of Intellect: Monograph], K. : Nora-Druk [in Ukrainian]. 
It is worth reminding that $\mathrm{G}$. Ball ${ }^{34}$ distinguishes the problem from the problem situation - a set of objects that allows a systematic representation in the form of a problem, but the one that has not yet received such representation.

He also distinguishes the problem from its sign model, the partial case of which is a verbal description (formulation).

We call a problem any situation, practical or theoretical, in which there is no obvious appropriate to circumstances decision and that is why it requires a break and consideration. Depending on how the situation is perceived by the subject, problem setting either takes place or does not take its place in the task ${ }^{35,36}$. We can assume that the transition from a problem situation to a problem is caused by a special manifestation of the subject's vigorous actions - excessive situative activity, which characterizes the tendency of the subject to act above the threshold of external or internal situational need, or go beyond the initial situation ${ }^{37}$.

V. Petrovsky distinguishes two levels of such activity: the phenomenon of "excessive situationality", that is, the redundancy of the subject's actions with respect to the requirements of the situation, which determine the criteria for the effectiveness of his behavior and are taken as initial ones, and "counter-situationality" when the subject acts contrary to incentives that restrict his / her free development. The main feature of the phenomena of excessive situational activity is that "the subject, acting in the direction of realization of the initial requirements of the situation, goes beyond these requirements; activity

${ }^{34}$ Ball, G. A. (2019). Bazovyie poniatiia obshchei teorii zadach. [Basic Concepts of the General Theory of Problems.] ... // Aktualni problemy psykholohii: Zb. nauk. prats Instytutu psykholohii imeni H. S. Kostiuka NAPN. Vol. U111, Psykholohichna teoriia i tekhnolohiia navchannia [Psychological Theory and Technology of Learning], vol. 10. Kyiv, 33-55. [in Russian]

35 Smulson, M. L. (2003). Psykholohiia rozvytku intelektu: monohrafiia [Psychology of Development of Intellect: Monograph], K. : Nora-Druk[in Ukrainian].

36 Poddiakov, A. N. (2015). Psikhologiia obucheniia v usloviiakh novizny, slozhnosti, neopredelennosti [Yelektronniy resurs] [The psychology of Learning in the Context of Novelty, Complexity, Uncertainty [Electronic resource]. / A. N. Podd'yakov // Psikhologicheskiye issledovaniya [Psychological research]. T. 8, № 40. S. 6. URL: http://psystudy.ru

${ }^{37}$ Petrovskiy, V. A. (1992). Psikhologiya nadadaptivnoi aktivnosti [Psychology of Adaptive Activity]. M.: TOO «Gorbunok» [in Russian] 
moments appear at the same time as if they were separated and not related to the facts of the subject "exit" beyond the situation boundaries" 38 . Such "exit beyond" the problem situation is observed, in our opinion, in case of the subject (group) transition to independent problem setting and attempts to solve it.

The problem-setting stage needs to be considered in all problems, but especially in those that arise in practical work. Finding a future problem - a problem situation - is one of the most important properties of an expert's intellect.

The problem differs from the problem situation in that it is consciously recognized by the subject, objectified and most often described verbally or in another sign (numeric, graphic form). The problem setting contains its analysis and understanding at a certain level, preliminary definition of the conception of the decision, strategy, and action plan. It, as a rule, involves taking into account the possible realistically available problem solving means (ie. material, materialized and ideal objects that are not directly included in the conditions of the problem, but are involved in solving it).

Hereafter, the stage of building problem structure is highlighted as the most important stage of the solving process ${ }^{39}$. A problem structure is understood a well-ordered model of a problem situation, which includes ideal objects, their functions, purpose (the ordering operation separates the desired objects from the data in the condition). This issue is called differently: understanding the problem, building a problem situation model and so on. According to many studies, this aspect plays an important role in the process of solving any problem. Apart from the very issue of constructing (detecting) a problem structure, the issue concerning the means of its explicit description, as well as some formalized "language" for such a description are equally important. Adequate language of the problem structure promotes the convergence of objective and subjective problem structures.

${ }^{38}$ Petrovskiy, V. A. (1992) .Psikhologiya nadadaptivnoi aktivnosti [Psychology of Adaptive Activity]. M.: TOO «Gorbunok». S. 15. [in Russian].

39 Mashbyts, Yu. I. (2019). Psykholohichni mekhanizmy i tekhnolohiia navchannia [Psychological mechanisms and technology of teaching]. K.: Interservis [in Ukrainian]. 
This gave us a reason to highlight the construction and description in a special formalized "language" of the problem structure in designing problem solving processes as intellectual activity as a separate sub-problem, and in terms of formation - learning an effective strategy for building a problem structure (along with the subsequent learning of an effective strategy to transform the problem structures). As for the descriptive "language" of a problem structure, it must become an integral part of the whole set of tools for solving similar problems.

Thus, intellectual training can be argued that it provides cooperative learning activity with its main attributes: free exchange of thoughts, creative character of search, interdependence and interresponsibility, reflection of one's own and partners' activity, management of one's own and partners' activity, etc.

In addition, it provides an opportunity to construct the learning process so that the direct product of students' activities is not the digestion of certain content, which in the context of traditional learning meets the closest learning goals, but the formation of those abilities that correspond to the components of our intended intellect in their interconnection. The construction of the educational process is aligned with the experimental and genetic method, because, firstly, it is based on a model (project) of the psychological phenomenon, which must be formed. Secondly, it provides other regularities of students' activity and development of projected ability in comparison with the patterns in traditional learning. Thirdly, the development of this psychological phenomenon in the conditions of experimental training, built according to the model (project) and theoretical ideas about the learning process is investigated. Fourthly, the design of our training process concerning preparation for the problem solution allows us to construct the educational process so that those psychological abilities that in the conditions of traditional training meet the distant goals, in the experimental training act as those that meet its immediate goals.

\section{CONCLUSIONS}

All in all, the practical implementation of the designed educational process requires a fundamentally new approach to building an educational impact system as a way of managing learning activities. The learning impact system was organized into a learning environment 
that we called intellectually rich, since the learning impacts were aimed at setting and solving intellectual problems. The most important features of such an environment are that it is characterized by such features as the problematicity and uncertainty of the environment, over-objectivity of the environment, the metacognitive nature of the environment, the processivity of the environment, the intellectual potentiality of the environment, the integrative and activity nature of the environment. In addition, the activity in the environment is invaluable, tolerant, that is, in intellectual training the concept of error, evaluation - neither process nor result - by other participants or the trainer is not used, except self-evaluation and one's own comparison with one's objective results. Fluid and crystallized intellect interact in the environment, which is achieved through inclusion of experts' groups of all ages. Decentrality and group nature of the environment should also be noted. The implementation of these characteristics acted as certain requirements for the project development of the environment.

Means of providing, ie creation and maintenance, project characteristics in the real training process are multifunctional problem situations and psychotechnical procedures are designed on their basis. Intellectual saturation of the environment is achieved by introducing to it specially designed (sprout) problem situations of different content and structure and constructing appropriate psychotechnical procedures on their basis. It is a fundamental moment in designing and maintaining the problematicity of the environment, because in this approach the problem situations are really only "potential problems", and the elements of vision, reconstruction, minimization-deployment of problem situations and tasks in the multi-vector field of professional activity are simulated in the environment.

The environment, designed in this way, enables the extension of problem types used in it as well as the predominant orientation to setting and solving non-standard problems, namely: problems for setting problems and moving from a problem situation to a problem using different "languages" of its description, problems on reflection, problems concerning the situation forecast and transformation, situations concerning one's own and partners' activity management as well as joint activity organization, etc. Intellectual activity in the environment when solving any problem requires constant 
metacognitive monitoring advanced intellectual and interpersonal ("inter-intellectual") reflection. In other words, constructing a "world of problems", one's own intellectual and partners' activities takes place in the environment, which contributes to the amplification and transformation of mental models of the world ${ }^{40,41,42}$.

\section{SUMMARY}

In the problem-based approach to activity, proposed by $\mathrm{H}$. Kostiuk and his followers, activity is seen as a system of problem solving processes. In order to start (initiate) a professional activity, the problem, which the subject feels, sees, etc., turns into a task and begins to work on it, to solve it, is nessecery. This situation of self-assignment of the professional problem has the greatest effectiveness in terms of self-study and, accordingly, professional self-development.

The modern process of preparation for professional activity focuses primarily on situations of high complexity and involves a high level of independence and subjectness of the student, in particular, in setting and solving problems in the activity; reorganization of systems of learning problems to approximate them to the real ones and, accordingly, orient them to the requirements of multifacetedness, continuity, dynamics, immensity, efficiency, etc.; refusal from the rigid guidance on the error-free activity; special work on the development of self-search skills and setting tasks in the activity. These aspects of preparation for problem solving in a professional activity are effectively realized through the use of intellectual training, ie specially organized group work on setting and solving different types of professional problems.

40 Smulson, M. L. (2003). Psykholohiia rozvytku intelektu: monohrafiia [Psychology of Development of Intellect: Monograph], K. : Nora-Druk[in Ukrainian].

${ }^{41}$ Smulson, M. L. (2009). Intelekt i mentalni modeli svitu [Intellect and Mental Models of the World] / Naukovi doslidzhennia kohnityvnoi psykholohii [Scientific and Cognitive Psychology]. Ostroh: Vyd-vo Natsionalnoho universytetu "Ostroh", Vol. 12, 38-49 [in Ukrainian].

42 Smulson, M.L. \& oth. (2015). Intelektualnyi rozvytok doroslykh u virtualnomu osvitnomu prostori: monohrafiia [Adult intellectual development in the virtual educational space: a monograph]. Kyiv : Pedahohichna dumka. URL: http://lib.iitta.gov.ua/10064. [in Ukrainian]. 


\section{REFERENCES}

1. Ball, G. A. (2019). Bazovyie poniatiia obshchei teorii zadach [Basic Concepts of the General Theory of Problems.] ... // Aktualni problemy psykholohii: Zb. nauk. prats Instytutu psykholohii imeni H. S. Kostiuka NAPN. Vol. U111, Psykholohichna teoriia i tekhnolohiia navchannia [Psychological Theory and Technology of Learning], vol. 10. Kyiv, 33-55. [in Russian].

2. Ball, G. A., Margulis, Ye. D., Rybalka, V. V., Chmut. T. K., Samoylov, A. Ye. (1983). Issledovaniia protsessa postanovki zadachi i ikh pedagogicheskoye znacheniye [Investigations of the Problem Setting Process and Their Pedagogical Significance]. // Programmirovannoye obucheniye [Programmed Training]. Vyp. 20. Kiyev. S. 39-47. [in Russian].

3. Ball, G. A. (1990) Teoriia uchebnykh zadach: Psikhologopedagogicheskii aspekt [Theory of Educational Problems: Psychological and Pedagogical Aspect]. M.: Pedagogika. 184 s. [in Russian].

4. Chepelieva, N. V. (2019). Rozviazannia smyslovykh zadach yak chynnyk samoproektuvannia osobystosti [Solving Meaningful Problems as a Factor of Self-Design of Personality]. Aktualni problemy psykholohii: Zb. nauk. prats Instytutu psykholohii imeni H. S. Kostiuka NAPN Ukrainy [Current Problems of Psychology: a collection of scientific works of H. S. Kostiuk Institute of Psychology of the National Academy of Pedagogical Sciences of Ukraine]. T. U111, Psykholohichna teoriia i tekhnolohiia navchannia [Psychological Theory and Technology of Learning], vol. 10. K., P. 300-313 [in Ukrainian].

5. Kaneman, D. (2014). Dumai medlenno... reshai bystro [Think Slowly ... Decide Fast]. / Daniel Kaneman. M.: AST. 315 s. [in Russian].

6. Kaneman, D., Slovik, P., Tverski, D. (2018). Prinyatiie reshenii $\mathrm{v}$ neopredelennosti. Pravila i predubezhdeniya [Decision Making in Uncertain Situations: Rules and Biases]. KH. : Izd-vo "Gumanitarnyi Tsentr". 536 s. [in Russian].

7. Karpov, A. V. (2011). Psikhologiia soznaniia: Metasistemnyi podkhod [Psychology of Consciousness: Metasystem Approach]. M.: RAO. 1088 s. [in Russian]. 
8. Kholodnaia, M. A. Psikhologiya intellekta [Psychology of Intelligence]. Paradoksy issledovaniia [Paradoxes of Research]. Moskva-Tomsk: Izd-vo Tom. un-ta, 1997. 392 s. [in Russian].

9. Klein, G. (2008). Naturalistic Decision Making. Human Factors / Klein G. // The Journal of the Human Factors and Ergonomics Society. 50(3). P. 456-460. [in English].

10. Knauff, M., Wolf, A. G. (2010). Complex Cognition: the Science of Human Reasoning, Problem-Solving, And DecisionMaking / Knauff M., Wolf A.G. // Cognitive Processesing. 11 (2). P. 99-102.

11. Kornilov, Yu. K. (2014). Na puti k psikhologii prakticheskogo myshleniia [On the Way to the Psychology of Practical Thinking]. M.: Izd-vo "Institut psikhologii RAN". 407 s. [in Russian].

12. Kornilov, Yu. K. (1997). O razlichiiakh metakognitsii uchebnoy i professionalnoi deiatelnosti [About the Differences in Metacognitions of Educational and Professional Activities]. // Kognitivnoie obucheniie: sovremennoie sostoianiie i perspektivy [Cognitive Learning: Current Status and Prospects]. / Pod red. T. Galkinoy i E. Lourera. M.: Izd-vo "Institut psikhologii RAN". S. 191-200. [in Russian].

13. Kostiuk, H. S. (1969). Princip razvitiia v psihologii [The Development Principle in the Psychology]. Metodologicheskiie i teoreticheskiie problemy psihologii [Methodological and Theoretical Problems of Psychology]. M. : Nauka [in Russian].

14. Maksymenko, S. D. (2019). Aktualni problemy henetychnoi psykholohii [Actual Problems of Genetic Psychology] Aktualni problemy psykholohii: $\mathrm{Zb}$. nauk. prats Instytutu psykholohii imeni H. S. Kostiuka NAPN Ukrainy. [Actual problems of psychology: Collection of scientific works of the H.S. Kostiuk Institute of Psychology of the National Academy of Pedagogical Sciences of Ukraine.] T. U111, Psykholohichna teoriia i tekhnolohiia navchannia [Psychological Theory and Technology of Learning], vol. 10., Kyiv., 8-20 [in Ukrainian].

15. Mashbyts, Yu. I. (2019). Psykholohichni mekhanizmy i tekhnolohiia navchannia [Psychological mechanisms and technology of teaching]. K.: Interservis [in Ukrainian]. 
16. Petrovskiy, V.A. (1992) .Psikhologiya nadadaptivnoi aktivnosti [Psychology of Adaptive Activity]. M.: TOO "Gorbunok" [in Russian].

17. Poddiakov, A. N. (2015). Psikhologiia obucheniia v usloviiakh novizny, slozhnosti, neopredelennosti [Yelektronniy resurs] [The psychology of Learning in the Context of Novelty, Complexity, Uncertainty [Electronic resource]. / A. N. Podd'yakov // Psikhologicheskiye issledovaniya [Psychological research]. T. 8, № 40. S. 6. URL: http://psystudy.ru [in Russian].

18. Smulson, M. L. (2003). Psykholohiia rozvytku intelektu: monohrafiia [Psychology of Development of Intellect: Monograph], K. : Nora-Druk [in Ukrainian].

19. Smulson, M. L. (2009). Intelekt i mentalni modeli svitu [Intellect and Mental Models of the World] / Naukovi doslidzhennia kohnityvnoi psykholohii [Scientific and Cognitive Psychology]. Ostroh: Vyd-vo Natsionalnoho universytetu "Ostroh", Vol. 12, 38-49 [in Ukrainian].

20. Smulson, M. L. \& oth. (2015). Intelektualnyi rozvytok doroslykh u virtualnomu osvitnomu prostori: monohrafiia [Adult intellectual development in the virtual educational space: a monograph]. Kyiv : Pedahohichna dumka. URL: http://lib.iitta.gov.ua/ 10064. [in Ukrainian].

21. Smulson, M. L. (2019). Rozvytok dorosloi liudyny u suchasnomu tranzytyvnomu sviti [Adult development in the modern transitive world]. Aktualni problemy psykholohii: Zb. nauk. prats Instytutu psykholohii imeni H.S.Kostiuka NAPN Ukrainy [Current problems of psychology: a collection of scientific works of the H. S. Kostiuk Institute of Psychology of the National Academy of Pedagogical Sciences of Ukraine]. T. U111, Psykholohichna teoriia i tekhnolohiia navchannia [Psychological theory and technology of teaching], vol. 10, Kyiv, 257-267 [in Ukrainian].

22. Smulson, M. L. (2017). Mistse zadachi v intelektualnii diialnosti // Pedahohika i psykholohiya: Visnyk NAPN Ukrayiny [The Place of the Problem in Intellectual Activity // Pedagogy and Psychology: Bulletin of the National Academy of Pedagogical Sciences of Ukraine]. № 2 (95). S. 40-48. 
23. Teplov, B. M. (1961). Um polkovodtsa [The Mind of the Commander]. / B. M. Teplov // Problemy individual'nykh razlichiy [Problems of Individual Differences]. M.: APN RSFSR. S. 252-344. [in Russian].

\section{Information about the author:}

Maryna Smulson

Doctor of Psychological Sciences, Professor,

Real member of National Academy of Pedagogical Sciences of Ukraine,

Head of Department of Modern Information Technologies of Education, G. S. Kostiuk Institute of Psychology, National Academy of Pedagogical Sciences of Ukraine 2 Pankivska str., Kyiv, 01033, Ukraine ORCID ID: orcid.org/0000-0002-9563-3390 E-mail: smulson@ukr.net 